NBER WORKING PAPER SERIES

THE COST OF CARING FOR YOUNG CHILDREN

\author{
Dan T. Rosenbaum \\ Christopher J. Ruhm \\ Working Paper 11837 \\ http://www.nber.org/papers/w11837 \\ NATIONAL BUREAU OF ECONOMIC RESEARCH \\ 1050 Massachusetts Avenue \\ Cambridge, MA 02138 \\ December 2005
}

The authors are collaborators on a study of inequality in early childhood education and care, funded by the Russell Sage Foundation as part of its Social Inequality program. We would like to thank Eric Wanner and the Foundation for their support. Ruhm gratefully acknowledges additional funding for this research from the National Institute of Child Health and Human Development. Address correspondence to Ruhm at: Department of Economics, Bryan School of Business and Economics, UNCG, Greensboro, NC 27402-6165.The views expressed herein are those of the author(s) and do not necessarily reflect the views of the National Bureau of Economic Research.

(C2005 by Dan T. Rosenbaum and Christopher J. Ruhm. All rights reserved. Short sections of text, not to exceed two paragraphs, may be quoted without explicit permission provided that full credit, including () notice, is given to the source. 
The Cost of Caring for Young Children

Dan T. Rosenbaum and Christopher J. Ruhm

NBER Working Paper No. 11837

December 2005

JEL No. J13, J18, J22

\begin{abstract}
$\underline{\text { ABSTRACT }}$
This study examines the "cost burden" of child care, defined as day care expenses divided by aftertax income. Data are from the wave 10 core and child care topical modules to the 1996 Survey of Income and Program Participation. We estimate that the average child under six years of age lives in a family that spends 4.9 percent of after-tax income on day care. However, this conceals wide variation: 63 percent of such children reside in families with no child care expenses and 10 percent are in families where the cost burden exceeds 16 percent. The burden is typically greater in singleparent than married-couple families but is not systematically related to a measure of socioeconomic status that we construct. One reason for this is that disadvantaged families use lower cost modes and pay less per hour for given types of care. The cost burden would be much less equal without low cost (presumably subsidized) formal care focused on needy families, as well as government tax and transfer policies that redistribute income towards them.
\end{abstract}

Dan T. Rosenbaum

Department of Economics

University of North Carolina at Greensboro

P.O. Box 26165

Greensboro, NC 27402-6165

rosenbaum@uncg.edu

Christopher J. Ruhm

Department of Economics

University of North Carolina at Greensboro

P.O. Box 26165

Greensboro, NC 27402-6165

and NBER

chrisruhm@uncg.edu 


\section{The Cost of Caring for Young Children}

How much of their income do parents spend on day care for their young children? To our knowledge, this study provides the first comprehensive study of this seemingly simple question. ${ }^{1}$ There are two main reasons why we know so little about what we call the "cost burden of child care", defined as child care expenses divided by family incomes. First, it is difficult to compile data that simultaneously provides accurate information on day care expenses and family incomes. Second, conceptualizing the cost burden is surprisingly complex, since parental employment and child care use are closely linked (Hofferth et al., 1991 and Smith, 2002), with the result that parents (particularly mothers) who work typically utilize more nonparental care than those who do not. ${ }^{2}$ One implication is that employment often raises both the numerator (expenses) and the denominator (family incomes) in the child burden equation. The positive relationship between child care spending and family income is even stronger for femaleheaded households, where labor supply is a greater determinant of total family income and child care use. Other complicating issues include the measurement of income (e.g. gross versus disposable income, family versus household), permanent versus transitory components of income and expenses, and possible changes in family composition over time.

Our analysis addresses five specific questions. First, what is the average cost burden of caring for children under six years of age? Second, how does this burden differ across types of families? Third, do child care costs increase or lower measured income inequality? Fourth, how would inequality in the cost burden change if the modes or costs of care became more similar

\footnotetext{
${ }^{1}$ Some indication of child care expenses relative to income has previously been provided by Hofferth et al. (1991), Anderson and Levine (2000), and Smith (2002). Giannarelli and Barsimantov's (2002) research is most closely related to this analysis but is limited to families where the primary caregiver is working.

${ }^{2}$ Child care expenses also influence parental employment. Anderson and Levine (2000) and Meyers et al. (2004) review the related research and conclude that most estimates of the elasticity of maternal employment with respect to child care expenses cluster around -0.3 or -0.4 .
} 
across groups than they currently are. Finally, do government tax and transfer policies and child care subsidies exacerbate or mitigate differences in the cost burden of child care?

This analysis utilizes the 1996 panel of the Survey of Income and Program Participation (SIPP), which contains detailed data on both child care expenses and income. Our information on child care comes from the wave 10 topical module covering the period March through June 1999; that on income is from the wave 10 core survey providing information on average incomes in the preceding four months. We also use data from the March Current Population Survey (CPS) to construct a measure of socioeconomic status (SES) that is based on predicted income percentiles and use the National Bureau of Economic Research (NBER) TAXSIM program to estimate taxes for our SIPP families.

We estimate that the average child under the age of six lives in a family that spends 4.9 percent of their after-tax income on child care. This conceals a wide variation: 63 percent of such children reside in families with no (non-immediate family) day care expenses and 10 percent are in families where the cost burden exceeds 16 percent. A large portion of differences in the cost burden are related to family characteristics. For example, children living with married parents are in families where the average cost burden is 3.9 percent, compared to an average cost burden of 7.4 percent for families with an absent spouse or never married parent.

Income inequality is somewhat greater when measured net of child care expenses than when these costs are not taken into account (the Gini coefficient rises from 0.398 to 0.406 ). However, the child care cost burden is not systematically related to SES, as proxied by predicted incomes. The reason for this is that disadvantaged families use lower cost modes and pay less per hour for given types of child care. Equalizing costs per hour (and presumably differences in the quality of care received) would dramatically increase the cost burden of disadvantaged 
families. Finally, our evidence suggests that government policies operate to reduce inequality of the child care cost burden. This primarily reflects the redistributed effects of tax policies and the role of the Earned Income Tax Credit. Transfer payments have smaller effects.

\section{Previous Evidence on the Cost Burden of Child Care}

Previous research provides some information on the cost burden of child care. Using the 1990 National Child Care Survey, Hofferth et al. (1991) report that child care expenses, for families with children under five and who pay for care, are 10 percent when the mother is employed and 6 percent when she is not. They also provide evidence that cost burdens decline with income. However, as shown below, there is an important role for care that is provided free of charge, making it difficult to use these statistics to determine the cost burden for all families, not just those paying for care. ${ }^{3}$

Anderson and Levine (2000) and Casper (1995) report cost burdens computed from the 1993 (and earlier) panels of the SIPP but are limited because these data refer only to families with caregivers who are working or in school. ${ }^{4}$ Anderson and Levine estimate that child care expenses are 7 percent of income, for families with children under six and employed mothers paying for care; Casper (1995) obtains a corresponding cost burden of 7.6 percent for families with children under five years of age. However, neither study accounts for free child care or families with nonworking mothers. These exclusions are important - accounting for 68 percent of all children in the sample we analyze.

Giannarelli and Barsimantov (2000) provide the most comprehensive previous study of the cost burden of child care. Using the 1997 National Survey of American Families (NSAF), they find that families with children under 13 pay 9.2 percent of their income for child care.

\footnotetext{
${ }^{3}$ Meyers et al. (2004) attempt to do so by combining findings from a number of tables in Hofferth et al. (1991).

${ }^{4}$ Hofferth (1996) and Blau (2001) provide additional analyses of the statistics reported by Casper.
} 
However, the analysis is again limited to paid care and to families with an employed caregiver. Also, the NSAF does not break down child care costs by mode.

The "Who's Minding the Kids?" reports by the U.S. Census Bureau (Smith, 2002) used the 1996 SIPP panel to examine how the cost burden varies by group. Smith reports that child care expenses are 6.6 percent of income, for families making payments, and is considerably higher for low-income families that pay for care. But once again, describing the cost burden is not the primary focus and it is extremely difficult to ascertain how the cost burden differs across all families. To reiterate, free care is important and studies neglecting to consider it miss out on one of the primary determinants of differences in the cost of care.

The analysis below improves on the previous literature in five ways. First, we calculate the cost burden for all families with young children, not just those with employed parents. Second, we carefully consider the role of both paid and free child care. Third, we examine difference in modes and costs per mode of care. Fourth, we consider child care expenses as a fraction of disposable rather than gross income (removing taxes and adding in transfer payments). Fifth, we emphasize the distribution of the cost burden, not just the average value.

\section{Data}

The Survey of Income and Program Participation is is a multistage-stratified sample of the U.S. civilian noninstitutionalized population, sponsored by the U.S. Census Bureau, that provides extensive available information on both child care use and expenditures and income. SIPP households are interviewed every four months (each interview is a wave) for periods of up to four years. The survey is built around detailed monthly "core" questions on labor force activity, program participation and sources of income. These are supplemented by wave-specific 
“topical modules". 5 We use a recent topical SIPP module on child care use, wave 10 of the 1996 panel, covering the period from March 1999 through June $1999 .{ }^{6}$ Our sample contains 4,524 families with 5,777 children under the age of six. ${ }^{7}$ A primary caregiver (typically the mother) is designated for each family. ${ }^{8}$

The focus of this paper is calculating the "child care cost burden," defined as expenditures on child care (obtained from non-immediate family members) divided by after-tax income. The SIPP topical module contains extremely detailed questions on child care costs. ${ }^{9}$ Variables for usual weekly child care costs are separately provided for each of the five youngest children (under six) and for each of seven non-immediate family child care arrangements (grandparent, other relative, family day care, day care center, pre-school/nursery school, Head Start, and other non-relative). ${ }^{10}$ Data for both the working and non-working caregivers is collected in the 1996 SIPP.

Income data come from the core questionnaire and are measured as a monthly average over the four months prior to the survey. ${ }^{11}$ Total family income includes earnings, government

\footnotetext{
${ }^{5}$ Further information on the SIPP can be obtained at: http://www.sipp.census.gov/sipp.

${ }^{6}$ Similar child care data are collected in wave 4 of the 1996 SIPP panel. Earlier SIPP panels also collect child care information that, as previously mentioned, is limited to caregivers who are working or in school. The SIPP also collects data on children aged 6 to 14 which (because our focus is on young children) is not used in this analysis.

${ }^{7}$ These are obtained from the full 1996 SIPP panel of 36,700 households (most of whom do not have children or children in the designated age range).

${ }^{8}$ This is the mother in married-couple families and the sole parent in single parent families. Grandparents and other relatives can also be designated as the primary caregiver.

${ }^{9}$ The extreme level of detail may have hindered the efforts of previous researcher to compute child care costs using the 1996 panel of the SIPP. For example it is necessary to read in 105 variables in order to compute: the total cost of child care (for children five years and younger), total child care hours per week, and total child care hours per week when the primary caregiver is working.

${ }^{10}$ Also included are hours of care, hours of care while the caregiver was working, and place of care, as well as similar variables for care by immediate family members including the other parent and older siblings.

${ }^{11}$ We use a four-month average in order to minimize the effects of transitory fluctuations.
} 
transfers (Temporary Assistance to Needy Families, Unemployment Compensation, and Social Security), non-government transfers (e.g. alimony and child support payments), and unearned income (dividends, property income, and pensions). ${ }^{12}$

We also estimate the taxes paid by each family, using TAXSIM which has been developed by the National Bureau of Economic Research. ${ }^{13}$ In doing so, we break families into tax-filing units (single, head of household, married filing jointly), compute income (federal and state) and payroll (Social Security and Medicare) taxes for each tax-filing unit, and sum these to get total taxes. TAXSIM is sophisticated in its treatment of different types of income (e.g. earned versus Social Security income), and in allowing child care expenses to be included in child care credit calculations. $^{14}$

When calculating the child care cost burden, we assume a minimum after-tax family income of $\$ 314$ per month (corresponding to the $5^{\text {th }}$ percentile in our sample) and cap the cost burden at a maximum of 50 percent. We make these adjustments for several reasons. First, since incomes are averaged over only a four month period, very low (and zero) measured incomes will often represent transitory reductions (e.g. during periods of temporarily reduced employment). Second, families with incomes below the $5^{\text {th }}$ percentile may be able to afford

\footnotetext{
${ }^{12}$ In SIPP, all household members are part of the primary family, except for married couples or single caregivers and their nonadult children, where neither spouse (or the single caregiver) is the household head.

${ }^{13}$ For more information on TAXSIM, see Feenberg and Coutts (1993) and TAXSIM (2003).

${ }^{14}$ Data limitations require that we make several simplifying assumptions. Most importantly, lacking good information on itemized deductions, we assume that all tax-filing units take the standard deduction. We also assume that only child care expenses for family day care, day care centers, pre-school/nursery schools, and Head Start are claimed for tax purposes. To compute annual income and child care expenses, we multiply our monthly averages incomes by twelve and weekly child care expenses by 52 . Maine and Vermont are combined into one state group, in the SIPP, as are North Dakota, South Dakota, and Wyoming. To compute state income taxes for these states, we constructed a population-weighted average for families residing in the specified group of (two or three) states.
} 
child care because they reside in households with income support provided by other adults. ${ }^{15}$ Although a full investigation of the distinction between family and household incomes is beyond the scope of this analysis, we provide some information on this issue below. Third, the cost burden is capped because it seems unlikely that many families would be able to spend more than half of their income on child care expenses for extended periods of time.

We often compare results for families with different predicted incomes, using the latter as a proxy for socio-economic status (SES). When doing so, predicted income is estimated using data from the 1998 through 2002 March Current Population Survey (CPS) and controlling for gender, age, education, race/ethnicity, and state of residence of the primary caregiver, as well as all second-level interactions between these variables. ${ }^{16}$ Children in the SIPP are ranked by predicted family incomes, based upon characteristics of their primary caregiver and the CPS model estimates, and then grouped into six categories representing the: $0-10,10-25,25-50,50-$ 75, 75-90, and 90-100 predicted income percentiles. ${ }^{17}$ Compared to grouping children by a single characteristic (e.g. the education of their mother), this method but has the advantage of simultaneously accounting for a large number of determinants of SES.

For ease of exposition, we use several conventions throughout the paper. First, we sometimes refer to caregivers (who are occasionally grandparents or other guardians) as "parents" but in all cases are talking about all caregivers. Second, we split the sample into three

\footnotetext{
${ }^{15}$ The average family with monthly income less than $\$ 314$ lives in a household with a monthly income of $\$ 1,670$.

${ }^{16}$ The age groups include $<20,20-24,25-29,30-34,35-39,40-44,45-49$ and 50+ individually and $<28,28-34$, and $35+$ for the interactions. The educational groups include high school dropout, high school graduate, some college but no bachelor's degree, bachelor's degree, and master's degree or higher. The last two educational groups are combined for the interactions. The race/ethnicity groups are white non-Hispanic, black non-Hispanic, other nonHispanic, and Hispanic. Each state, except those grouped in the SIPP, are entered individually, but the states are grouped into five regions for the interactions. The CPS income variable is equivalent to that used in the SIPP, prior to deducting taxes.

${ }^{17}$ Children with predicted incomes at the dividing point between categories are placed into the lower group (e.g. children at the $10^{\text {th }}$ percentile are placed in the $0-10^{\text {th }}$ and not the $10-25^{\text {th }}$ percentile).
} 
marital status groups - married with spouse present, spouse absent (married with spouse absent, widowed, divorced, or separated), and never married - and refer to the latter two groups as "single parents," even though it is possible that these caregivers cohabit. Third, our results provide nationally representative estimates for children aged 0 through $5 .{ }^{18}$ While we occasionally we discuss findings for "caregivers" or "families," these technically refer to children under the age of six in those families. Fourth, except where noted, reported child care hours and costs are for arrangements outside of the immediate family (the other parent and siblings). Fifth, all child care costs and incomes are measured as monthly, while child care hours generally are reported as weekly. To compute monthly child care costs, we multiply our weekly child care costs by 52 weeks and divide by 12 months.

\section{Use and Cost of Child Care}

Care of young children by persons outside the immediate family is common but not universal. As detailed in Table 1, children under six years of age reside in families where an average of 25 hours of day care per week is supplied outside the immediate family (other than parents and siblings) at a cost of $\$ 135$ per month, with external care used by roughly three-fifths of families. This care costs an average of $\$ 1.24$ per hour, which is sharply divided between that generally provided very cheaply by grandparents or other relatives (averaging $\$ 0.31$ per hour) and that that supplied at an average cost of around \$2 per hour in day care centers, pre-schools, or other less formal settings (with the exception of the virtually free care supplied by Head Start). These differences explain why two-fifths of child care is provided free of charge, including three-quarters of that by grandparents or other relatives, versus around one-fifth of hours by non-

\footnotetext{
${ }^{18}$ These are obtained by multiplying SIPP person weights by the number of children for the given caregiver.
} 
relatives in informal settings and only one-tenth to one-eighth of care in family day care facilities, centers, and preschools. ${ }^{19}$

Approximately 40 percent of the 25 hours of average weekly non-immediate family child care is provided by grandparents or other relatives; 8 hours weekly occurs in day care centers or pre-schools; 7 hours per week in family day care centers or by non-relatives in informal settings; and less than 1 hour through the federal Head Start program (although this is probably an undercount). ${ }^{20}$ In addition, an average of six hours per week of supervision is provided by the parents other than the designated caregiver and less than one hour weekly by siblings. ${ }^{21}$ The remainder of our analysis focuses exclusively on care by non-immediate family members and the related discussion refers only to these sources of care.

The amount and costs of child care vary substantially across types of families. For instance, single parent families use 50 percent more child care than those with married parents (33 vs. 22 hours per week) but utilize much cheaper sources ( $\$ 0.80$ vs. $\$ 1.50$ per hour) and, as a result, spend 20 percent less per week (\$114 vs. \$143). Similarly, families where the caregiver is a non-Hispanic white use slightly fewer hours of day care than minorities ( 24 vs. 27 hours per week) but pay more both per hour (\$1.49 vs. \$0.87) and per month $(\$ 155$ vs. \$100) for these

\footnotetext{
${ }^{19}$ These figures represent lower-bounds on the percentage of free child care because no free care is assigned in cases where families receiving some hours at no charge and pay for other hours of care within a given mode (e.g. if a grandparent provides some portion of care for free and is paid for the rest). We suspect that the resulting understatement is small.

${ }^{20}$ In Table 1 we are estimating that approximately 200,000 children are in Head Start in a given month. In the 1999 fiscal year, there were 826,016 children enrolled in Head Start at a cost of $\$ 4.7$ billion (U.S. Department of Health and Human Services, 2000). Part of this undercount is due to our time period stretching into the summer months, when Head Start programs are not in session. However, we suspect that a more important reason is because most Head Start children may be counted in some of the other modes of care. For example, we estimate that there are nearly 600,000 three and four year-old children in families with incomes less than the median income (about $\$ 2,500$ per month) receiving free or less than a dollar per hour care in day care centers, pre-schools, or nursery schools. Many of these children may be Head Start children.

${ }^{21}$ For immediate family members (siblings and the other parent), only hours of care while the primary caregiver is working or in school are counted in the SIPP.
} 
services. By contrast, more educated parents use both large amounts and expensive sources of care, and so have relatively high expenditures.

The child care burden depends on the type and cost of care, as well as on the family incomes. Thus, it represents a complicated interaction of a variety of factors that often move in different directions. Groups using smaller amounts of care often utilize more expensive sources and so have greater total expenditures. These same groups (e.g. married couple families) also often have relatively high family incomes so that it is not obvious, a priori, which types of families have the highest cost burdens. As mentioned, this issue is even more complicated because employment and child care use are jointly determined and because there are likely to be substantial within-group differences in all of these factors. We explore these issues below.

\section{What is the Cost Burden of Child Care?}

As shown on the first row of Table 2 , the average $0-5$ year old child is in a family paying 4.9 percent of their disposable income on day care. ${ }^{22}$ This average, however, conceals enormous diversity in the child care burden. Fully 63 percent of children live in families with no expenses, implying that the median cost burden is 0 percent. Conversely, the average child care burden for families in the upper 10 percent of the distribution is nearly 30 percent of disposable income. ${ }^{23}$ As noted above, the absence of child care costs does not imply that no day care is used -23 percent of children are in families that utilize only free sources of care. Note, also, that the average burden rises to 13.0 percent if the sample is limited to the 32 percent of the sample with working caregivers who pay for care, as is done in most previous analyses (Smith, 2002;

\footnotetext{
${ }^{22}$ Calculation of the average cost burden is somewhat sensitive to the treatment of the small number of children in families with very high burdens, usually occurring because of low average incomes over the four month period over which these are calculated. Fewer than 2 percent of children are affected by the 50 percent maximum we use in calculating the cost burden. If this maximum were raised to 75 percent (100 percent) the average burden would increase to 5.2 (5.3) percent. There is no effect on the lower 98 percent of the cost burden distribution.

${ }^{23}$ The $75^{\text {th }}, 90^{\text {th }}$, and $95^{\text {th }}$ percentiles of the cost burden distribution are 5.9, 16.3, and 25.3 percent.
} 
Anderson and Levine, 2000; and Giannarelli and Barsimantov, 2000). ${ }^{24}$ Limiting the sample to this sub-group ignores much of the variation in the burden across families.

Perhaps the most noteworthy finding in Table 2 is the remarkable concentration of the child care burden. Families in the upper 10 percent of the distribution pay an average $\$ 624$ per month for care, versus $\$ 80$ per month for the other 90 percent of families. Yet, these high cost burden families have disposable incomes of just $\$ 2,268$ per month, lower than the $\$ 3,150$ for the other 90 percent. Part of the reason for this difference is that 40 percent (versus 15 percent) of the high cost burden caregivers are working single parents.

The cost burden of child care, and its components, differs substantially and in mostly predictable ways with the demographic characteristics of the primary caregiver. Table 3 stratifies the sample by race/ethnicity, marital status, education, geographic location, the number of children, and age of the youngest child. As mentioned, the cost burden is lower in marriedcouple families (3.9 percent) than in those where the caregiver has never been married (7.0 percent) or where the spouse no longer lives with the child (7.9 percent). The average cost burden is also relatively high for black families (6.0 percent), but not for other types of minorities, and for those with multiple young children (5.9 percent). Interestingly, the cost burden rises monotonically with education, from 3.9 percent for high school dropouts to 5.4 percent for college graduates. This reflects the somewhat higher child care hours and much greater costs of the most educated group, and occurs despite their high family incomes. By

\footnotetext{
${ }^{24}$ Smith (2002), using wave 4 of the 1996 SIPP, reports that among families with at least one child under five who pay for care, the average child care payment over the average pre-tax income is 8.9 percent. In our sample, the analogous statistic is 7.5 percent (but our figure excludes families with 6-14 year old year old but no younger children). Anderson and Levine (2000), using SIPP panels from the early 1990s, report an average child care burden of 7.7 percent of pre-tax income among working caregiver families with at least one child under six who pay for care; However, this includes costs of only primary and secondary arrangements, with a cap of $\$ 140$ per week for each. Using 1997 NSAF data, Giannarelli and Barsimantov (2000) report an average child care burden of 9.2 percent of pre-tax income among working caregiver families who pay for care. Their measure is for families with children under 13, a group likely to have lower expenses than for families that all include a child under six.
} 
contrast, the high cost burdens of single parent households reflect low incomes, with particularly long hours being offset by the use of cheap sources of day care.

There is also substantial variation in the distribution of the child care cost burden within groups (see Table 4). For instance, almost four-fifths of children with a high school dropout parent are in families with no child care costs, compared to under half of those where the caregiver is a college graduate; however, the cost burden at the $90^{\text {th }}$ percentile is similar $(15.0$ percent versus 15.9 percent). Conversely, the relatively high average cost burdens for children with black caregivers or in single parent families result from increased costs at the top of the distribution (as indicated by the $75^{\text {th }}$ and $90^{\text {th }}$ percentiles), with little difference in the fraction of such families experiencing positive child care costs.

Many of the differences in child care cost burdens, highlighted in Tables 3 and 4 reflect the common influences of factors that vary in similar ways across sub-samples. For instance, since black children have relatively high probabilities of being raised in single parent families, some of the racial differences could result from disparities in marital status rather than other race effects. With this in mind, Table 5 presents partial correlations between demographic factors and the cost burden, remaining after controlling for other observable characteristics. The dependent variable in the first column is the average cost burden and the equation is estimated by OLS. The second and third columns present estimated marginal effects from binary probit models (with other covariates evaluated at the sample means) for dichotomous dependent variables indicating if the child's family has any child care costs and if the cost burden exceeds the $90^{\text {th }}$ percentile (16.3 percent). Robust standard errors are also displayed, calculated assuming independence for children across but not within families. 
The econometric estimates confirm many of the previously described patterns. Single parent families have relatively high cost burdens, as do those with highly educated parents and large numbers of young children. Interestingly, single parents appear to be particularly concentrated among those with cost burdens above the $90^{\text {th }}$ percentile, even accounting for other demographic characteristics - a finding hinted at in many of the earlier tables. Characteristics associated with high average cost burdens are usually positively related to the probability of having positive expenses or being above the $90^{\text {th }}$ percentile of the distribution. There are, however, some exceptions (e.g. Hispanic children are especially likely to live in families with no costs but also marginally more likely to live in those with cost burdens above the $90^{\text {th }}$ percentile). A noteworthy finding is that the previously observed substantial differences between white and black children largely disappear with the inclusion of controls for other covariates.

\section{Do Child Care Costs Increase Inequality?}

The issue of income inequality has received a great deal of attention in recent years, in part because of its sharp rise during the 1980s and early 1990s after several decades of decline. ${ }^{25}$ The growth of income inequality can be traced, in large part, to increasing wage inequality (Katz and Autor, 1999) but also to growth in single motherhood, particularly among less-skilled women (Ellwood and Jencks, 2004). The consequences of the changing wage structure have been partially offset by increases in women's labor force participation (U.S. Bureau of the Census, 2001; and Mishel, Bernstein, and Schmidt, 2001), raising the question of whether child care costs mitigate or exacerbate inequality.

We address this question by comparing inequality in family income with and without accounting for child care costs. The results of this exercise, presented in Table 6, suggest that

\footnotetext{
${ }^{25}$ Jones and Weinberg (2000) report that between 1975 and 1993, households in the $90^{\text {th }}$ percentile saw their incomes rise by 21.8 percent, while those in $10^{\text {th }}$ percentile experienced decreases of 2.3 percent.
} 
income inequality modestly increases when child care expenses are subtracted from disposable income. For example, the Gini coefficient rises from 0.398 to 0.406 and the ratio of incomes at the $90^{\text {th }}$ and $10^{\text {th }}$ percentiles of the distribution (the $90 / 10$ ratio) increases from 7.78 to 8.52 . Similarly, the 50/25 and 25/10 ratios grow from 1.67 and 2.08 to 1.71 and 2.23. The top panel of the table reveals that the increase in inequality occurs primarily because of disproportionately large reductions in net incomes at the bottom of the distribution (e.g. 13 percent at the $10^{\text {th }}$ percentile versus less than 5 percent at the $90^{\text {th }}$ percentile), while median incomes are relatively unaffected (falling just 4 percent) so that there is little change in the 90/50 or $75 / 50$ ratio.

The results just discussed refer to a sample of families with young children. If these families have relatively low incomes, as seems likely, the preceding calculations will understate the rise in inequality resulting from netting out child care expenses. ${ }^{26}$ On the other hand, our main income variable removes taxes and transfer payments, and therefore is not directly comparable to that typically used in prior research. We investigate government tax and transfer policies below.

\section{How Does the Child Care Cost Burden Differ With Socioeconomic Status?}

The remainder of our analysis examines how child care costs and the cost burden differ with SES. We are interested in determining whether "disadvantaged" families face the double problem of low incomes and high child care cost burdens, or if they have lower burdens because of using less hours or cheaper sources of day care.

As previously discussed, we sort families into SES groups by: 1) estimating predicted incomes from CPS data, with controls for age, education and race/ethnicity of the primary caregiver, as well as many interactions between these variables; 2) ranking SIPP children by

\footnotetext{
${ }^{26}$ For example, the families in our sample have median annual (pre-tax) incomes of $\$ 34,668$. The corresponding median income for all U.S. families, in 1999, was \$48,950 (U.S. Bureau of the Census, 2001, Table 668.)
} 
predicted family income, based upon characteristics of their primary parent; 3) grouping them into into six categories representing the: $0-10,10-25,25-50,50-75,75-90$, and 90-100 predicted income percentiles. In addition to providing a single summary measure of SES, rather than relying on multiple correlated indicators, this method has the advantage of removing the effects of caregiver-specific variation in work hours (that is likely to be correlated with both family incomes and child care use and costs). However, it should be noted that the effects of betweengroup variation in average employment or child care use will not be removed. For instance, persons with high predicted incomes may have relatively high child care costs because this group is dominated by educated parents who supply relatively large amounts of market labor.

Sample characteristics for the six predicted income categories, summarized in Appendix Table A.1, largely accord with our expectations. Groups with low predicted incomes are dominated by minorities, single-parent families, and less educated caregivers, whereas whites, married-couple families, and educated caregivers are disproportionately represented among those with high expected incomes. For example, the primary parent of 48 percent of children in the 0 $10^{\text {th }}$ percentile is nonwhite, 34 percent are Hispanic, 67 percent have no spouse present, and 69 percent are high school dropouts; the corresponding percentages for children in the $90-100^{\text {th }}$ percentile are 6 percent, 3 percent, 5 percent, and 0 percent. ${ }^{27}$ Parents of the latter group work many more hours (68 versus 29 hours), largely due to the presence of the spouse in the family. Conversely, there is much more likely to be a non-parent working adult in the household for the $0-10^{\text {th }}$ than the $90-100^{\text {th }}$ percentile (41 versus 3 percent), with the result that the family provides a

\footnotetext{
${ }^{27} \mathrm{We}$ also calculated predicted income percentiles using an equation that add controls for marital status and the number of children (and selected interactions) to the set of explanatory variables. The patterns are generally similar to those obtained without these additional variables, although (not surprisingly) with an even larger representation of single-parent families in the lower SES groups and slightly less delineation by educational attainment. The results discussed below are also fairly similar when using this alternative predicting equation.
} 
much lower share of total household income for the lower SES group (68 versus 99 percent). ${ }^{28}$

One implication is that calculating the cost burden as the ratio of child care costs to household (rather than family) income might result in a considerably lower figure at the bottom of the predicted income distribution but would have little effect for high SES individuals. ${ }^{29}$ This represents an important subject for future research.

Table 7 details how the cost burden of child care and its components varies with both actual income and with SES as proxied by predicted family income. The burden falls monotonically with actual incomes because increases in the latter more than offset the rising hours and cost of care. For instance, day care use care is almost twice as large for families in the $90-100^{\text {th }}$ than for those in the $0-10^{\text {th }}$ percentiles ( 30.5 vs. 16.4 hours per week) and their monthly child care costs are more than six times higher (\$313 vs. \$47) but these differences are dwarfed by an almost 30 -fold difference in average incomes (\$8,534 vs. \$288). However, a significant portion of these differences are due to the endogeneity between employment and child care use those working more have both higher incomes and greater child care expenses. This can be seen in the lower panel of the table, where the link between predicted incomes and child care use and costs is much less pronounced.

The most striking finding is the absence of any consistent pattern between predicted income and the cost burden. The burden for the $0-10^{\text {th }}, 25-50^{\text {th }}$, and $90-100^{\text {th }}$ percentiles are

\footnotetext{
${ }^{28}$ A complication with measuring the cost burden at the family-level is the treatment of multi-generation households. Family definitions in the SIPP and CPS result in differences in the treatment of other adults in the household (such as grandparents). In particular, when the family head is not the household head, other adults generally will not count in family income calculations, whereas if the family and household head are the same they will not.

${ }^{29}$ However, it is also possible that other adults in the household have young children of their own, in which case the cost burden for the entire household might not fall. Moreover, without a full understanding of intra-household income transfers it is somewhat difficult to know how to interpret a cost burden measure that is based upon household incomes.
} 
virtually identical ( 5.5 or 5.6 percent) and substantially lower for the $25-50^{\text {th }}, 50-75^{\text {th }}$ and $75-90^{\text {th }}$ percentiles (4.7, 4.1 and 4.2 percent). The lack of a monotonic relationship results from offsetting increases in actual incomes and child care costs when moving up the predicted income distribution. For instance, families in the $90-100^{\text {th }}$ percentile spend 1.3 times as much on day care as those in the $25-50^{\text {th }}$ percentile and have incomes that are 1.4 times as high.

The other remarkable feature is the similarity in child care hours across predicted income groups. Although the categories with the highest average cost burdens (the $0-10^{\text {th }}, 25-50^{\text {th }}$, and $90-100^{\text {th }}$ percentiles) also use the most child care, these differences are dwarfed by disparities in the costs of care. For example, the $90-100^{\text {th }}$ percentile obtain 20 percent more hours of child care per week than the $50-75^{\text {th }}$ percentile ( 27.9 vs. 23.2 hours) but pays over twice as much for it (\$269 vs. \$129 per month).

Table 8 provides information on differences in the use and cost of specific modes of child care across SES categories. Notice that the similarity in total hours of care, just discussed, masks substantial variation in the choice of modes. Families at the bottom of the predicted income distribution obtain a large proportion of total care from relatives, whereas those at the top get most care from centers, preschools, or family day care facilities. Specifically, the $0-10^{\text {th }}$ percentile obtains almost half of total care hours from grandparents or other relatives compared to less than a fifth of hours for the $90-100^{\text {th }}$ percentile. Conversely, the former group gets 31 (7) percent of care from centers and preschools (family day care) compared to 43 (19) percent for the latter.

The distribution of monthly child care spending is detailed in the bottom panel of Table 8. The bulk of child care expenditures are devoted to paying for formal care in centers, preschools, and family day care facilities - these three modes account for 63 percent of the 
monthly child care spending for the $0-10^{\text {th }}$ predicted income percentiles, 56 percent for the 10 $50^{\text {th }}$ percentiles and 73 to 76 percent for the $50-100^{\text {th }}$ percentiles.

Families with high predicted incomes not only use more expensive types of care but also pay more for any given mode. As shown in the top panel of Table 9, the $90-100^{\text {th }}$ percentile spends 133 percent more per hour for center/pre-school care than the $0-10^{\text {th }}$ percentile $(\$ 2.75$ vs. \$1.18), 81 percent extra for family day care (\$2.39 vs. \$1.32), 66 percent more for informal nonrelative care ( $\$ 2.42$ vs. $\$ 1.46$ ), and over twice as much for supervision by relatives ( $\$ 0.63$ vs. $\$ 0.23)$.

It seems likely that the extra spending by families with high predicted incomes purchases higher quality care. However, costs for the bottom of the distribution are probably being reduced by day care subsidies offered by the government, employers, or others. The middle panel of the table, which investigates the frequency with which child care is provided without cost to the family, supplied evidence in support of this. In particular, the use of free care provided by nonrelatives is much more common at the bottom of the predicted income distribution than at the top, as expected if subsidies are targeted to disadvantaged families,. Thus, 19 percent of the center-based care is supplied to the $0-10^{\text {th }}$ percentile without charge, compared to 7 percent for the $90-100^{\text {th }}$ percentile. Free care is also much more likely to be provided to low SES families by non-relatives. Conversely, almost all hours in family day care settings are paid for, whereas care by relatives is usually free.

Families at the bottom of the predicted income distribution are also much less likely to pay more than $\$ 1$ per hour for center-based care (see the bottom panel of Table 9), providing a further indication that they receive a disproportionate share of subsidized care. For example, the $0-10^{\text {th }}$ and $10-25^{\text {th }}$ percentiles spend over $\$ 1$ for 44 and 53 percent of center/pre-school hours, 
compared to over 85 percent for families in the top two predicted income categories.

Consequently, children in families in the $0-10^{\text {th }}$ percentile spend about 20 percent of their 26

hours per week in free or low cost ( $\$ 1$ per hour or less) center-based care (including Head Start), 44 percent in free or low cost care with relatives, and only 31 percent in care costing more than a dollar per hour. Children in the $10-25^{\text {th }}$ percentile spend 11 (51) percent of their 25 hours per week in free or low cost center-based care (relative care) and only about 28 percent in care costing more than a dollar per hour. On the other hand, children in the $90-100^{\text {th }}$ percentile spend 76 percent of their 28 hours per week in care costing more than a dollar per hour and just 15 percent in free or low cost care with relatives.

\section{Household Accommodations and Government Policies}

The section examines how government policies and household accommodations affect the cost burden of child care. Table 10 focuses on how tax and transfer policies that cause net and gross incomes to differ. As shown in the first three rows of the table, earnings are by far the largest source of total incomes for all SES categories, with those of the caregiver being far more important at the bottom than the top of the distribution. The caregiver provides 51 percent of earnings for the $0-10^{\text {th }}$ percentile and 41 percent for the $10^{\text {th }}-25^{\text {th }}$ percentile, compared to just 28 and 30 percent among the $75-90^{\text {th }}$ and $90-100^{\text {th }}$ percentiles. This largely reflects the high share of single parent families among the low SES categories.

Government transfers result in a modest redistribution towards disadvantaged families: such payments account for 18 percent of net incomes among the bottom 10 percent (60 percent due to welfare) and less than one percent for the top decile. Although such transfers are large enough to more than pay for the child care expenditures of the bottom half of the distribution, if 
they were targeted to families with high child care expenses, most of the payments are actually received by those with no child care costs. ${ }^{30}$

Income and payroll taxes have much larger effects on disposable income. We estimate that taxes reduce the net incomes of the top two SES groups by 25 and 28 percent, compared to less than 8 and 4 percent for the bottom two. The modest reductions in incomes for disadvantaged families occur even though payroll taxes (for Social Security and Medicare) are approximately proportional to incomes. The most important reason is that federal income taxes are particularly low for these families, in large part due to the Earned Income Tax Credit (EITC), which creates strong employment incentives and rapidly phases out at higher incomes (Meyer and Rosenbaum, 2001). ${ }^{31}$ Finally, federal child tax credits and federal and state child care credits have modest effects on net incomes for all groups. However, the EITC and Child Care Credit are more targeted towards families with high day care expenses than are transfer payments. ${ }^{32}$

The first row of the Table 11 repeats the information from Table 7, showing that the cost burden of child care remains relatively constant across predicted income categories. The remainder of the table estimates of how the cost burden would change under several scenarios. These counterfactuals assume that families use the same amount of family day care as in the base case, and examine the effects of government tax/transfer policies (which affect net incomes) or

\footnotetext{
${ }^{30} \mathrm{We}$ calculate that families in the bottom half of the predicted income distribution could pay for just 14 percent of their child care costs with their transfer payments; in the bottom decile this percentage rises to 22 percent.

${ }^{31}$ Our calculations assume that all families take the standard income tax deduction. Since high income families are more likely to itemize, we are overstating income taxes (by a larger amount) for high SES families and therefore also overestimating the redistribution due to the tax system. Using data from the SIPP, we estimate that this overstatement is sizable, but that it has very little effect on our cost burden measure. Allowing for itemized deductions would likely result in $0.9,1.2,2.3,3.9,3.6$ and 7.4 increases the after-tax income $0-10^{\text {th }}, 10-25^{\text {th }}, 25-50^{\text {th }}$, $50-75^{\text {th }}$ and $90-100^{\text {th }}$ percentiles of the predicted income distribution. Overall, this would lower the cost burden by about 0.11 percentage points ( 4.86 to 4.75 percent) with families in the $90-100^{\text {th }}$ percentile experiencing about a 0.23 percentage point decrease, and the rest of the distribution experiencing between a 0.06 and 0.16 percentage point decrease in the cost burden.

${ }^{32} \mathrm{We}$ calculate that families in the bottom half of the predicted income distribution could pay for 29 percent of their child care costs with the Earned Income Tax and Child Care Credits; in the bottom decile this rises to 36 percent.
} 
changes in the type or cost per hour of the care utilized (which affect expenditures). The simulations do not account for the substitution towards cheaper types or fewer hours of care that might occur when costs per hour increase. Nor do they account for the changes in modes that would accompany different government tax/transfer policies.

As mentioned, transfer policies have little effect on the child care cost burden. The second row shows that removing this source of income would increase the child care burden for the bottom decile of the predicted income distribution from 5.6 to 6.1 percent, while having smaller effects on the $10^{\text {th }}-75^{\text {th }}$ percentiles and none at all for the top quartile. By contrast, eliminating taxes would have no effect on the bottom 25 percent but (by increasing disposable incomes) would sharply reduce the cost burden of the top half of the distribution. For instance, the burden of the $75-90^{\text {th }}$ and $90-100^{\text {th }}$ percentiles would fall from 4.2 to 3.4 percent and 5.5 to 4.3 percent (see the third row of the table). ${ }^{33}$

The SIPP does not provide complete information on subsidized sources of care. To estimate the effects of eliminating such subsidies (whether they come from government or private sources) we assume that any day care provided in centers, pre-schools or family day care facilities at a cost of less than $\$ 1$ per hour is subsidized. We then calculate the expenses of nonsubsidized care by replacing the actual hourly costs of subsidized care with the sample average hourly cost for unsubsidized hours of care from these sources. ${ }^{34}$ The results of this exercise, shown in the fourth row of the table, indicate that the removal of subsidies would dramatically increase the cost burden of low SES families (e.g. from 5.6 and 4.7 percent to 8.9 and 6.6 percent

\footnotetext{
${ }^{33}$ These are all partial equilibrium effects because we assume that income and payroll taxes would be eliminated without replacing them by any offsetting source of government revenue.

${ }^{34}$ The average cost of care costing more than $\$ 1$ per hour in centers, preschools, and family day care facilities is $\$ 2.47$ per hour. Our calculations will understate the effects of removing subsidies if some care costing more than $\$ 1$ per hour is subsidized.
} 
for the $0-10^{\text {th }}$ and $10-25^{\text {th }}$ percentiles) and result in a substantial rise through the $75^{\text {th }}$ percentile of the predicted income distribution, while having smaller effects for the top quartile. These results further emphasize the importance of free and low cost sources of care in holding down the child care cost burden.

Since low SES families use cheaper types of child care and also pay less within modes, making patterns of day care use more similar along either of these dimensions would dramatically increase inequality in the cost burden of child care. As illustrated in the fifth row, equalization of the cost per hour within (but not across) modes of care, combined with existing patterns of use, would cause the average cost burden to rise from 5.6 to 9.6 percent for the $0-10^{\text {th }}$ percentile and from 4.7 to 6.9 percent for the $10-25^{\text {th }}$ percentile, whereas the burden would fall from 4.2 to 3.7 percent for the $75-90^{\text {th }}$ percentile and from 5.5 to 4.2 percent for the $90-100^{\text {th }}$ percentile. If the cost per hour of child care was equalized for all families (across as well as within modes), the average cost burden would be $12.6,9.8,3.5$, and 3.3 percent for the $0-10,10$ $25,75-90$, and $90-100^{\text {th }}$ percentiles (see row six).

The last row of Table 11 demonstrates the average cost burden if hours of day care were unchanged, taxes and transfer payments were eliminated, and all families paid the sample average amount for each hour of care. In this case, the burden of child care would be over twice as high as that actually observed for the $0-10^{\text {th }}$ percentiles ( 14.2 vs. 5.6 percent) and $10-25^{\text {th }}$ percentiles (11.3 vs. 4.7 percent), while declining by almost one-third for the $75-90^{\text {th }}$ percentile (from 4.2 to 2.9 percent) and by more than half for the highest decile (from 5.5 to 2.6 percent). Moreover, the families in the $0-10^{\text {th }}\left(10-25^{\text {th }}\right)$ percentiles would expect to spend over five (four) times as much of their income on child care as the top decile.

\section{Discussion}


Children under the age of six (in 1999) live in families spending an average of $\$ 135$ month on day care and with disposable incomes averaging $\$ 3,060$ per month. Dividing the first number by the second suggests that 4.4 percent of income is devoted to child care. This simple calculation provides a misleading indication of the child care burden for two reasons. First, it overweights higher income families. We calculate that the child care burden for the average family is a somewhat higher 4.9 percent. $^{35}$

More importantly, any calculation of the average cost burden conceals tremendous variation in child care spending. Perhaps most striking is that 63 percent of young children live in families that have no child care expenses. In roughly two-thirds of cases this is because no non-immediate family day care is used. However, the remainding families do use child care but pay nothing for it. The majority of free (or very low cost) care is provided by relatives (such as grandparents), although subsidized care in more formal settings is received by a substantial fraction of families.

Another noteworthy result is that average hours and cost burdens of child care are relatively constant across SES groups, as measured by predicted family income. For instance, the $0-10^{\text {th }}$ percentile average 26.3 hours of day care weekly and pay 5.6 percent of their income for it; the $90-100^{\text {th }}$ percentile use 27.9 hours per week and spend 5.5 percent of income on it. The similarity of cost burdens, despite much higher incomes at the top of the distribution, occurs because disadvantaged families make far more extensive use of cheaper types of care and pay less for any given mode. One likely implication is that at least some of the efforts made by

\footnotetext{
${ }^{35}$ Consider a sample of three families with child care costs of $\$ 79, \$ 98$, and $\$ 313$ and incomes of $\$ 1,152, \$ 1,990$, and $\$ 8,534$ (corresponding to the sample averages for families in the $10-25^{\text {th }}, 25-50^{\text {th }}$, and $90-100^{\text {th }}$ percentiles of the actual income distribution). Total spending on child care is $\$ 490$ and total incomes are $\$ 11,676$ implying that 4.2 percent of income is spent on day care. Conversely, the three families devote 6.9 percent, 4.9 percent, and 3.7 percent of their incomes to day care, imply that the average across families is 5.2 percent. The first procedure provides a smaller number because it weights the expenditures of high income families (who have smaller cost burdens) more heavily, whereas the second gives each family an equal weight in calculating the average.
} 
disadvantaged families to minimize the burden of child care come at the cost of accepting lower quality services. ${ }^{36}$ Our evidence also suggests that accounting for child care expenses would raise the extent of measured income inequality, providing further evidence of the difficult situation of the least advantaged families.

These results notwithstanding, the cost burden of child care (and the quality of services received) would probably be much more unequal were it not for the efforts of low SES families to minimize expenses, of government tax and transfer policies that redistribute resources towards needy families, and of low cost (presumably subsidized) formal care that is focused on them. For instance, if all families paid the same amount for each hour of day care but did not change the amount used, the cost burden for the $0-10^{\text {th }}$ and $10-25^{\text {th }}$ percentiles would rise from 5.6 and 4.7 percent to 12.6 and 9.8 percent, while those of the $75-90^{\text {th }}$ and $90-100^{\text {th }}$ percentiles would decline from 4.2 and 5.5 percent to 3.5 and 3.3 percent. Eliminating taxes and transfer payments would further raise cost burdens of the bottom two groups, to 14.2 and 11.3 percent, while lowering those of the top two to 2.9 and 2.6 percent. These comparisons ignore the behavioral responses that would accompany such changes (e.g. shifting to cheaper modes or reducing total child care hours by low SES families), but nevertheless suggest that the current policy environment provides at least some assistance to disadvantaged families.

Our results should be viewed with caution for several reasons. As mentioned, we have looked at the cost of care and make some inferences about quality but do not have direct information on the latter. Similarly, we use the presence of extremely low-cost formal care as

\footnotetext{
${ }^{36}$ There is also direct evidence that higher income families use higher quality care within modes (e.g. Galinsky, et al., 1994) and that more formal modes tend to offer higher quality of care (see Meyers et al., 2004 for a detailed discussion). Evidence that reductions in the cost of care cause parents to substitute market forms for less formal arrangements is provided by Michalopoulos and Robins 2002; Micholopoulos, Robins and Garfinkel 1992; Cleveland et al 1996; and Powell 1997. In his comprehensive study of child care choices, Blau (2001) concludes that "parents feel most 'priced out' of center and family day care and would prefer these types over other nonparental care and parental care if they were equally as cheap" (p. 74).
} 
evidence of subsidies, in the absence of direct data on these. Child care and family income will also sometimes be reported with error, particularly given the short period of time to which the data refer. This could be important since estimates of the average cost burden (but not most other distributional measures) are somewhat sensitive to the treatment of outliers. Another potential issue is the use of family rather than household incomes. Although the distinction is generally not important, since the family and household are usually one and the same, disadvantaged families relatively often reside in households containing other adults which, depending on the nature of within-household income transfers, has the potential for reducing child care cost burdens when measured as a percentage of family incomes. ${ }^{37}$

Much exciting research remains to be done.

\footnotetext{
${ }^{37}$ Using household rather than family incomes reduces the average cost burden from 4.9 to 4.4 percent and from 5.6 to 4.6 percent for the $0-10^{\text {th }}$ percentile, 4.7 to 3.9 percent for the $10-25^{\text {th }}$ percentile, 5.6 to 4.9 percent for the $25-50^{\text {th }}$ percentile, 4.1 to 3.8 percent for the $50-75^{\text {th }}$ percentile, 4.2 to 4.2 percent for the $75-90^{\text {th }}$ percentile, and 5.5 to 5.4 percent for the $90-100^{\text {th }}$ percentile of the predicted income distribution.
} 


\section{References}

Anderson, Patricia, and Philip Levine (2000). "Child Care and Mother's Employment Decisions." In Findings Jobs: Work and Welfare Reform, edited by David Card and Rebecca Blank. New York: Russell Sage Foundation, pp. 420-462.

Blau, David M. (2001). The Child Care Problem. New York: Russell Sage Foundation, 2001.

Casper, Lynne M. (1995). "What Does It Cost to Mind Our Preschoolers?" Washington, DC: U.S. Bureau of the Census, Current Population Reports, P70-52, September 1995, http://www.census.gov/prod/1/pop/p70-52.pdf.

Cleveland, Gordon, Morley Gunderson, and Douglas Hyatt (1996). "Child Care Costs and the Employment Decision of Women: Canadian Evidence." Canadian Journal of Economics 29(1), pp. 132-51.

Ellwood, David, and Christopher Jencks (2004). “The Uneven Spread of Single-Parent Families: What Do We Know? Where Do We Look For Answers?” In Social Inequality, edited by Kathryn M. Neckerman. New York: Russell Sage Foundation, pp. 3-77.

Feenberg, Daniel Richard, and Elizabeth Coutts (1993). "An Introduction to the TAXSIM Model.” Journal of Policy Analysis and Management, 12(1), Winter 1993, pp 189-194.

Galinsky, Ellen, Carollee Howes, Susan Kontos, and Marybeth Shinn (1994). The Study of Children in Family Child Care and Relative Care: Highlights of Findings. New York: Families and Work Institute.

Giannarelli, Linda and James Basimantov (2000). "Child Care Expenses of American Families: Assessing the New Federalism.” Occasional Paper Number 40. Washington, DC: Urban Institute, December 2000.

Hofferth, Sandra L. (1996). "Child Care in the United States Today." The Future of Children: Financing Child Care, 6(2), Summer/Fall 1996, pp. 41-61.

Hofferth, Sandra L., April Brayfield, Sharon Deich, and Pamela Holcomb (1991). National Child Care Survey, 1990. Washington, D.C.: Urban Institute Press.

Jones, Arthur F., Jr. and Daniel Weinberg (2000). “The Changing Shape of the Nation's Income Distribution (1947-1998)." Washington, DC: U.S. Bureau of the Census, Current Population Reports, P60-204, June 2000, http://www.census.gov/prod/2000pubs/P60204.pdf.

Katz, Lawrence F. and David H. Autor (1999). "Changes in the Wage Structure and Earnings Inequality." In Handbook of Labor Economics, Volume 3A, edited by Orley Ashenfelter and David Card. New York and Oxford: Elsevier Science, North-Holland, pp. 1463-1555. 
Meyer, Bruce D. and Dan T. Rosenbaum (2001). "Welfare, the Earned Income Tax Credit, and the Labor Supply of Single Mothers." Quarterly Journal of Economics, 116(3), pp. 1063-1114.

Meyers, Marcia, Dan T. Rosenbaum, Christopher Ruhm, and Jane Waldfogel (2004). "Inequality in Early Childhood Education and Care: What Do We Know?" In Social Inequality, edited by Kathryn M. Neckerman. New York: Russell Sage Foundation, pp. 223-269.

Michalopoulos, Charles, Philip K. Robins, and Irwin Garfinkel (1992). “A Structural Model of Labor Supply and Child Care Demand.” Journal of Human Resources 27(1), pp. 166203.

Michalopoulos, Charles and Robins, Philip K. (2000). "Employment and Child Care Choices in Canada and the United States." Canadian Journal of Economics 33(2), pp. 435-470.

Mishel, Lawrence., and Jared Bernstein, and John Schmidt (2001). The State of Working America: 2000-2001. Ithaca, NY: ILR Press/Cornell University Press, 2001.

Powell, Lisa (1997). "Supply and Childcare Choice Decisions of Married Mothers." Journal of Human Resources 37(1), pp. 106-128.

Smith, Kristin (2002). "Who's Minding the Kids? Child Care Arrangements: Spring 1997." Washington, DC: U.S. Bureau of the Census, Current Population Reports, P70-86, July 2002, http://www.census.gov/prod/2002pubs/p70-86.pdf.

TAXSIM Version 5.0 (2003). Boston, MA: National Bureau of Economic Research, 2003, http://www.nber.org/ taxsim/taxsim-calc5/index.html.

U.S. Bureau of the Census (2001). Statistical Abstract of the United States. Washington, DC: U.S. Government Printing Office, 2001.

U.S. Department of Health and Human Resources (2000). "2000 Head Start Fact Sheet." Washington, DC: Head Start Bureau, 2000, http://www2.acf.dhhs.gov/programs/hsb/research/factsheets/00_hsfs.htm. 
Table 1:

Decomposing Child Care Hours and Costs

\begin{tabular}{|c|c|c|c|c|c|}
\hline $\begin{array}{l}\text { Type of Child Care/ } \\
\text { Caregiver Characteristic }\end{array}$ & $\begin{array}{c}\text { Hours } \\
\text { Per Week }\end{array}$ & $\begin{array}{c}\text { Percent } \\
\text { Using }\end{array}$ & $\begin{array}{l}\text { Dollars } \\
\text { Per Hour }\end{array}$ & $\begin{array}{l}\text { Dollars } \\
\text { Per } \\
\text { Month }\end{array}$ & $\begin{array}{c}\text { Percent } \\
\text { Receiving } \\
\text { Free Care }\end{array}$ \\
\hline \multicolumn{6}{|c|}{ Mode of Child Care: All Children } \\
\hline Non-Immediate Family & 25.0 & $60.2 \%$ & $\$ 1.24$ & $\$ 135$ & $39.0 \%$ \\
\hline Relative/Grandparent & 10.0 & $29.8 \%$ & $\$ 0.31$ & $\$ 13$ & $76.3 \%$ \\
\hline Non-Relative & 3.4 & $11.4 \%$ & $\$ 1.77$ & $\$ 26$ & $18.0 \%$ \\
\hline Family Day Care & 3.4 & $8.4 \%$ & $\$ 1.77$ & $\$ 26$ & $10.1 \%$ \\
\hline Center/Pre-School & 7.9 & $22.7 \%$ & $\$ 2.01$ & $\$ 69$ & $12.4 \%$ \\
\hline Head Start & 0.3 & $1.2 \%$ & $\$ 0.13$ & $\$ 0$ & $82.3 \%$ \\
\hline Immediate Family & 6.5 & $22.1 \%$ & & & \\
\hline Other Parent & 5.9 & $19.0 \%$ & & & \\
\hline Siblings & 0.6 & $4.0 \%$ & & & \\
\hline \multicolumn{6}{|c|}{ Use and Cost of Non-Immediate Family Child Care By Caregiver Characteristics } \\
\hline Non-Hispanic White & 24.1 & $61.1 \%$ & $\$ 1.49$ & $\$ 155$ & $34.3 \%$ \\
\hline Non-White/Hispanic & 26.6 & $58.9 \%$ & $\$ 0.87$ & $\$ 100$ & $46.3 \%$ \\
\hline Spouse Present & 21.9 & $56.0 \%$ & $\$ 1.50$ & $\$ 143$ & $32.7 \%$ \\
\hline Spouse Absent/Never Married & 32.9 & $71.3 \%$ & $\$ 0.80$ & $\$ 114$ & $50.1 \%$ \\
\hline High School Dropout & 20.2 & $46.0 \%$ & $\$ 0.72$ & $\$ 63$ & $52.5 \%$ \\
\hline High School Graduate & 24.2 & $58.9 \%$ & $\$ 0.95$ & $\$ 99$ & $44.1 \%$ \\
\hline Beyond High School & 27.0 & $65.5 \%$ & $\$ 1.51$ & $\$ 177$ & $33.3 \%$ \\
\hline
\end{tabular}

Source: Data are from wave 10 of the 1996 panel of the Survey of Income and Program Participation (SIPP), covering the period from March through June 1999.

Standard errors: Standard errors range between 0.0-0.5 hours/week for use of care, $0.2 \%-0.7 \%$ for probability of using the specified type of care, $\$ 0.03-\$ 0.07$ for cost/hour, $\$ 0-\$ 4$ for cost $/$ month, and $0.9 \%-1.7 \%$ for the probability of free care (except for Head Start where it is 5.8\%) for all children. Corresponding standard errors for all non-immediate family child care among the specified population sub-samples range from 0.5-1.1 hours/week, 0.9\%-1.8\%, \$0.04-\$0.06/hour, \$5-\$6/week, and 1.0\%$2.5 \%$.

Note: Sample includes 4,524 caregivers of children aged 0 through 5. Observations are weighted using SIPP person weights multiplied by the number of children aged 0 through 5 , to provide nationally representative estimates for children of these ages. The use of specified modes sums to over 100 percent because some families use multiple types of day care. Child care hours for the immediate family are only for when the caregiver is working or in school. See the text for additional details. 
Table 2:

Sample Distributions of Child Care Burden and Its Components

\begin{tabular}{lccccc}
\hline & Sample & \multicolumn{3}{c}{ Cost Burden Percentile } \\
Cost Burden Component & Mean & $\mathbf{0 - 6 3}$ & $\mathbf{6 3 - 7 5}$ & $\mathbf{7 5 - 9 0}$ & $\mathbf{9 0 - 1 0 0}$ \\
\hline Child Care Cost Burden & $4.9 \%$ & $0 \%$ & $3.1 \%$ & $10.1 \%$ & $29.7 \%$ \\
& $(0.1 \%)$ & $(0 \%)$ & $(0.1 \%)$ & $(0.1 \%)$ & $(0.5 \%)$ \\
Monthly Child Care Costs & $\$ 135$ & $\$ 0$ & $\$ 145$ & $\$ 365$ & $\$ 624$ \\
& $(\$ 4)$ & $(\$ 0)$ & $(\$ 6)$ & $(\$ 7)$ & $(\$ 20)$ \\
Weekly Child Care Hours & 25.0 & 12.5 & 29.1 & 47.5 & 65.1 \\
& $(0.5)$ & $(0.5)$ & $(1.1)$ & $(1.0)$ & $(1.8)$ \\
Monthly Family Income & $\$ 3,060$ & $\$ 2,708$ & $\$ 4,757$ & $\$ 3,706$ & $\$ 2,268$ \\
& $(\$ 39)$ & $(\$ 47)$ & $(\$ 156)$ & $(\$ 65)$ & $(\$ 84)$ \\
\hline
\end{tabular}

Source: Data are from wave 10 of the 1996 panel of the SIPP.

Note: Standard errors are in parentheses. In this table and later tables child care costs and hours refer to child care from non-immediate family members. Monthly family income is the average income from all sources (earned and unearned income) for the entire family over the previous four months, less estimated monthly income (state and federal) and payroll taxes. The child care cost burden is calculated as total child care costs divided by total family income. The cost burden is capped at a maximum of $50 \%$. See Table 1 and the text for additional details. 
Table 3:

Sample Average Characteristics By Child Care Cost Burden and Its Components

\begin{tabular}{|c|c|c|c|c|c|}
\hline Caregiver Characteristic & $\begin{array}{c}\text { Child } \\
\text { Care Cost } \\
\text { Burden }\end{array}$ & $\begin{array}{c}\text { Monthly } \\
\text { Child } \\
\text { Care } \\
\text { Costs }\end{array}$ & $\begin{array}{c}\text { Weekly } \\
\text { Child } \\
\text { Care } \\
\text { Hours }\end{array}$ & $\begin{array}{l}\text { Monthly } \\
\text { Family } \\
\text { Income }\end{array}$ & $\begin{array}{c}\text { Sample } \\
\text { Size }\end{array}$ \\
\hline Full Sample & $4.9 \%$ & $\$ 135$ & 25.0 & $\$ 3,060$ & 4,524 \\
\hline White & $4.8 \%$ & $\$ 141$ & 23.7 & $\$ 3,265$ & 3,652 \\
\hline Black & $6.0 \%$ & $\$ 115$ & 33.0 & $\$ 2,023$ & 655 \\
\hline Other Nonwhite & $2.5 \%$ & $\$ 85$ & 20.1 & $\$ 3,109$ & 217 \\
\hline Hispanic & $4.7 \%$ & $\$ 90$ & 22.1 & $\$ 2,231$ & 775 \\
\hline Spouse Present & $3.9 \%$ & $\$ 143$ & 21.9 & $\$ 3,712$ & 3,150 \\
\hline Spouse Absent & $7.9 \%$ & $\$ 134$ & 35.8 & $\$ 1,599$ & 569 \\
\hline Never Married & $7.0 \%$ & $\$ 101$ & 30.9 & $\$ 1,219$ & 805 \\
\hline High School Dropout & $3.9 \%$ & $\$ 63$ & 20.2 & $\$ 1,599$ & 780 \\
\hline High School Graduate & $4.6 \%$ & $\$ 99$ & 24.2 & $\$ 2,408$ & 1,386 \\
\hline Some College & $5.2 \%$ & $\$ 132$ & 26.3 & $\$ 3,112$ & 1,349 \\
\hline College Graduate & $5.4 \%$ & $\$ 234$ & 27.8 & $\$ 4,957$ & 1,009 \\
\hline 1 Child (Aged 0-5) & $4.1 \%$ & $\$ 105$ & 19.3 & $\$ 2,937$ & 3,404 \\
\hline$>1$ Child (Aged 0-5) & $5.9 \%$ & $\$ 176$ & 33.0 & $\$ 3,233$ & 1,120 \\
\hline Youngest Child Aged 0-2 & $5.3 \%$ & $\$ 145$ & 27.0 & $\$ 2,972$ & 2,413 \\
\hline Youngest Child Aged 3-5 & $4.3 \%$ & $\$ 120$ & 22.0 & $\$ 3,189$ & 2,111 \\
\hline Lives in Northeast & $4.7 \%$ & $\$ 139$ & 22.2 & $\$ 3,360$ & 785 \\
\hline Lives in Midwest & $5.0 \%$ & $\$ 135$ & 24.7 & $\$ 3,098$ & 1,065 \\
\hline Lives in South Atlantic & $6.0 \%$ & $\$ 155$ & 27.5 & $\$ 3,117$ & 723 \\
\hline Lives in South Central & $4.6 \%$ & $\$ 121$ & 28.2 & $\$ 2,712$ & 856 \\
\hline Lives in West & $4.3 \%$ & $\$ 128$ & 23.2 & $\$ 3,031$ & 1,095 \\
\hline
\end{tabular}

Source: Data are from wave 10 of the 1996 panel of the SIPP.

Note: See note on Table 1. The "Spouse Absent" category includes currently married persons whose spouse is absent as well as those who are divorced, separated, or widowed. See Tables 1 and 2 and the text for additional details. 
Table 4:

Distribution of the Child Care Cost Burden Within Groups

\begin{tabular}{lccccc}
\hline & Average & $\begin{array}{c}\text { \% With No } \\
\text { Child Care } \\
\text { Caregiver Characteristic }\end{array}$ & \multicolumn{2}{c}{ Cost Burden Percentile } \\
Cost Burden & Costs & 50th & 75th & 90th \\
\hline Full Sample & $4.9 \%$ & $62.9 \%$ & $0 \%$ & $5.9 \%$ & $16.3 \%$ \\
White & $4.8 \%$ & $62.1 \%$ & $0 \%$ & $5.9 \%$ & $15.8 \%$ \\
Black & $6.0 \%$ & $63.6 \%$ & $0 \%$ & $7.1 \%$ & $24.6 \%$ \\
Other Nonwhite & $2.5 \%$ & $75.7 \%$ & $0 \%$ & $0 \%$ & $8.9 \%$ \\
Hispanic & $4.7 \%$ & $73.3 \%$ & $0 \%$ & $2.5 \%$ & $17.7 \%$ \\
Spouse Present & $3.9 \%$ & $62.4 \%$ & $0 \%$ & $5.5 \%$ & $12.9 \%$ \\
Spouse Absent & $7.9 \%$ & $61.5 \%$ & $0 \%$ & $10.9 \%$ & $29.1 \%$ \\
Never Married & $7.0 \%$ & $65.9 \%$ & $0 \%$ & $6.1 \%$ & $28.9 \%$ \\
High School Dropout & $3.9 \%$ & $78.9 \%$ & $0 \%$ & $0 \%$ & $15.0 \%$ \\
High School Graduate & $4.6 \%$ & $68.0 \%$ & $0 \%$ & $4.8 \%$ & $16.5 \%$ \\
Some College & $5.2 \%$ & $60.1 \%$ & $0 \%$ & $7.1 \%$ & $16.8 \%$ \\
College Graduate & $5.4 \%$ & $48.5 \%$ & $6.8 \%$ & $7.9 \%$ & $15.9 \%$ \\
\hline
\end{tabular}

Source: Data are from wave 10 of the 1996 panel of the SIPP.

Note: See Tables 1 and 2 and the text for additional details. 
Table 5:

Econometric Estimates of the Correlates of the Child Care Cost Burden

\begin{tabular}{lccc}
\hline Regressor & $\begin{array}{c}\text { Cost } \\
\text { Burden }\end{array}$ & $\begin{array}{c}\text { No Child } \\
\text { Care Costs }\end{array}$ & $\begin{array}{c}\text { Cost Burden }> \\
\mathbf{9 0}^{\text {th }} \text { Percentile }\end{array}$ \\
\hline Age & $-.0009^{* *}(.0003)$ & $.0033^{*}(.0014)$ & $-.0032^{* *}(.0008)$ \\
Female & $.0127(.0121)$ & $-.0006(.0500)$ & $.0245(.0233)$ \\
Black & $-.0039(.0061)$ & $.0225(.0270)$ & $-.0104(.0132)$ \\
Other Nonwhite & $-.0194 * *(.0053)$ & $.1387 * *(.0331)$ & $-.0432(.0184)$ \\
Hispanic & $.0076(.0060)$ & $.0500^{*}(.0246)$ & $.0270(.0160)$ \\
Spouse Absent & $.0502 * *(.0088)$ & $-.0632^{*}(.0287)$ & $.1565 * *(.0260)$ \\
Never Married & $.0377 * *(.0069)$ & $-.0433(.0275)$ & $.1162 * *(.0222)$ \\
High School Dropout & $-.0147 * *(.0062)$ & $.1124 * *(.0256)$ & $-.0241(.0137)$ \\
Some College & $.0125 * *(.0047)$ & $-.0896 *(.0219)$ & $.0193(.0135)$ \\
College Graduate & $.0235^{* *}(.0047)$ & $-.2266^{* *}(.0248)$ & $.0412 *(.0178)$ \\
\# Children Aged 0-5 & $.0147 * *(.0046)$ & $-.0247(.0170)$ & $.0401 * *(.0087)$ \\
Age Youngest Child & $-.0013(.0011)$ & $-.0247 * *(.0055)$ & $-.0087 * *(.0033)$ \\
Lives in Midwest & $.0027(.0054)$ & $-.0516 *(.0264)$ & $-.0040(.0147)$ \\
Lives in South Atlantic & $.0135^{*}(.0067)$ & $-.0857 *(.0299)$ & $.0126(.0178)$ \\
Lives in South Central & $-.0018(.0058)$ & $-.0121(.0282)$ & $-.0142(.0152)$ \\
Lives in West & $-.0001(.0055)$ & $-.0317(.0270)$ & $-.0108(.0148)$ \\
\hline$*$ P & & &
\end{tabular}

$*$ for $\mathrm{P}<0.05$, ** for $\mathrm{P}<0.01$.

Source: Data are from wave 10 of the 1996 panel of the SIPP.

Note: Estimation is by OLS in the first column and binary probit in the next two. Observations are weighted using SIPP child weights (described in Table 1). The coefficient estimates give the predicted effect of a marginal change in the explanatory variable (with other regressors evaluated at their variable means for the probit models). Robust standard errors, estimated assuming that observations are independent across but not within families, are shown in parentheses. See Tables 1 and 2 and the text for additional details. 
Table 6:

Income and Inequality With and Without Deduction for Child Care Costs

\begin{tabular}{|c|c|c|c|c|c|c|}
\hline \multirow[b]{2}{*}{ Income Measure } & \multirow[b]{2}{*}{ Average } & \multicolumn{5}{|c|}{ Income Percentile } \\
\hline & & 10th & 25th & 50th & 75th & 90th \\
\hline Monthly Family Income & $\$ 3,060$ & $\$ 723$ & $\$ 1,503$ & $\$ 2,509$ & $\$ 3,996$ & $\$ 5,625$ \\
\hline \multirow{2}{*}{$\begin{array}{l}\text { Family Income Net of } \\
\text { Child Care Costs }\end{array}$} & $\$ 2,925$ & $\$ 631$ & $\$ 1,408$ & $\$ 2,405$ & $\$ 3,837$ & $\$ 5,375$ \\
\hline & Gini & \multicolumn{5}{|c|}{ Income Ratio } \\
\hline Income Measure & Coefficient & 90/10 & $90 / 50$ & $75 / 10$ & $75 / 25$ & $\mathbf{5 0 / 1 0}$ \\
\hline Monthly Family Income & 0.398 & 7.78 & 2.24 & 5.53 & 2.68 & 3.47 \\
\hline $\begin{array}{l}\text { Family Income Net of } \\
\text { Child Care Costs }\end{array}$ & 0.406 & 8.52 & 2.23 & 6.08 & 2.72 & 3.82 \\
\hline
\end{tabular}

Source: Data are from wave 10 of the 1996 panel of the SIPP.

Note: The top panel of the table shows incomes at different points of the distribution, with observations weighted using SIPP child weights (described in Table 1). The bottom panel displays the Gini coefficient and the ratios of incomes at specified percentiles of the income distribution. See Tables 1 and 2 and the text for additional details. 
Table 7:

Cost Burden and Its Components By Actual and Predicted Family Income

\begin{tabular}{lcccccc}
\hline & \multicolumn{7}{c}{ Actual Family Income Percentile } \\
Cost Component & $\mathbf{0 - 1 0}$ & $\mathbf{1 0 - 2 5}$ & $\mathbf{2 5 - 5 0}$ & $\mathbf{5 0 - 7 5}$ & $\mathbf{7 5 - 9 0}$ & $\mathbf{9 0 - 1 0 0}$ \\
\hline Child Care Cost Burden & $6.2 \%$ & $6.3 \%$ & $4.9 \%$ & $4.1 \%$ & $4.6 \%$ & $4.4 \%$ \\
Monthly Child Care Costs & $\$ 47$ & $\$ 79$ & $\$ 98$ & $\$ 133$ & $\$ 196$ & $\$ 313$ \\
Weekly Child Care Hours & 16.4 & 27.7 & 23.4 & 24.1 & 28.5 & 30.5 \\
Monthly Family Income & $\$ 288$ & $\$ 1,152$ & $\$ 1,990$ & $\$ 3,205$ & $\$ 4,716$ & $\$ 8,534$ \\
Sample Size & 488 & 706 & 1,105 & 1,150 & 647 & 428 \\
\hline & & $\mathbf{P r e d i c t e d}$ Family Income Percentile & \\
Cost Component & $\mathbf{0 - 1 0}$ & $\mathbf{1 0 - 2 5}$ & $\mathbf{2 5 - 5 0}$ & $\mathbf{5 0 - 7 5}$ & $\mathbf{7 5 - 9 0}$ & $\mathbf{9 0 - 1 0 0}$ \\
\hline Child Care Cost Burden & $5.6 \%$ & $4.7 \%$ & $5.6 \%$ & $4.1 \%$ & $4.2 \%$ & $5.5 \%$ \\
Monthly Child Care Costs & $\$ 83$ & $\$ 75$ & $\$ 115$ & $\$ 129$ & $\$ 180$ & $\$ 269$ \\
Weekly Child Care Hours & 26.3 & 24.9 & 25.9 & 23.2 & 23.8 & 27.9 \\
Monthly Family Income & $\$ 1,268$ & $\$ 1,637$ & $\$ 2,294$ & $\$ 3,437$ & $\$ 4,665$ & $\$ 5,570$ \\
Sample Size & 428 & 689 & 1,140 & 1,161 & 659 & 447 \\
\hline
\end{tabular}

Source: Data are from wave 10 of the 1996 panel of the SIPP.

Standard errors: Standard errors range between $0.2 \%-0.7 \%$ for child care cost burden, $\$ 6-\$ 23$ for monthly child care costs, $0.9-1.9$ hours/week for weekly child care hours, and $\$ 8-\$ 201$ for monthly family income.

Note: The top panel shows results for sub-samples stratified by actual family income. The bottom panel divides the sample by the predicted family income percentile, which is obtained by regressions of total family income on interactions of gender, race, age, education, and region, using data from the 1998 through 2002 March Current Population Survey (CPS). In both cases, SIPP caregivers are divided into the specified percentiles based upon the specified family income variable and sample means are calculated weighting observations by SIPP child weights (described in Table 1). See Tables 1 and 2 and the text for additional details. 
Table 8:

Decomposing Child Care Hours and Costs By Predicted Family Income

\begin{tabular}{lcccccc}
\hline & \multicolumn{7}{c}{ Predicted Family Income Percentile } \\
Type of Child Care & $\mathbf{0 - 1 0}$ & $\mathbf{1 0 - 2 5}$ & $\mathbf{2 5 - 5 0}$ & $\mathbf{5 0 - 7 5}$ & $\mathbf{7 5 - 9 0}$ & $\mathbf{9 0 - 1 0 0}$ \\
\hline & \multicolumn{7}{c}{ Weekly Child Care Hours } \\
All Non-Immediate Family & 26.3 & 24.9 & 25.9 & 23.2 & 23.8 & 27.9 \\
Relative/Grandparent & 12.8 & 14.2 & 10.7 & 9.0 & 7.4 & 5.1 \\
Non-Relative & 2.9 & 3.1 & 3.8 & 2.7 & 3.3 & 5.4 \\
Family Day Care & 1.8 & 2.0 & 3.5 & 3.7 & 4.3 & 5.3 \\
Center/Pre-School & 8.2 & 5.3 & 7.6 & 7.6 & 8.8 & 12.1 \\
Head Start & 0.6 & 0.3 & 0.3 & 0.3 & 0.0 & 0.0 \\
\hline & & & Monthly Child Care Costs & \\
All Non-Immediate Family & $\$ 83$ & $\$ 75$ & $\$ 115$ & $\$ 129$ & $\$ 180$ & $\$ 269$ \\
Relative/Grandparent & $\$ 13$ & $\$ 20$ & $\$ 15$ & $\$ 11$ & $\$ 8$ & $\$ 13$ \\
Non-Relative & $\$ 18$ & $\$ 13$ & $\$ 23$ & $\$ 20$ & $\$ 40$ & $\$ 57$ \\
Family Day Care & $\$ 10$ & $\$ 15$ & $\$ 22$ & $\$ 26$ & $\$ 37$ & $\$ 55$ \\
Center/Pre-School & $\$ 42$ & $\$ 27$ & $\$ 56$ & $\$ 72$ & $\$ 95$ & $\$ 144$ \\
Head Start & $\$ 0$ & $\$ 0$ & $\$ 0$ & $\$ 0$ & $\$ 0$ & $\$ 0$ \\
\hline
\end{tabular}

Source: Data are from wave 10 of the 1996 panel of the SIPP.

Standard errors: For weekly child care hours, standard errors range between 0.9-1.7 hours for all nonimmediate family, 0.6-1.1 hours for relative/grandparent, 0.3-1.0 hours for non-relative, 0.4-0.8 hours for family day care, 0.6-1.1 hours for center/pre-school, and 0.0-0.2 hours for Head Start. For monthly child care costs, standard errors range between $\$ 42-\$ 164$ for all non-immediate family, $\$ 2-\$ 5$ for relative/grandparent, $\$ 2-\$ 10$ for non-relative, $\$ 3-\$ 8$ for family day care, $\$ 4-13$ for center/pre-school, and less than $\$ 0.30$ for Head Start.

Note: See Table 7 for details. 
Table 9:

Decomposing Child Care Costs Per Hour By Predicted Family Income

\begin{tabular}{lcccccc}
\hline & \multicolumn{7}{c}{ Predicted Family Income Percentile } \\
Type of Child Care & $\mathbf{0 - 1 0}$ & $\mathbf{1 0 - 2 5}$ & $\mathbf{2 5 - 5 0}$ & $\mathbf{5 0 - 7 5}$ & $\mathbf{7 5 - 9 0}$ & $\mathbf{9 0 - 1 0 0}$ \\
\hline & \multicolumn{5}{c}{ Costs Per Hour for Child Care } \\
All Non-Immediate Family & $\$ 0.73$ & $\$ 0.70$ & $\$ 1.03$ & $\$ 1.29$ & $\$ 1.75$ & $\$ 2.23$ \\
Relative/Grandparent & $\$ 0.23$ & $\$ 0.32$ & $\$ 0.32$ & $\$ 0.28$ & $\$ 0.25$ & $\$ 0.60$ \\
Non-Relative & $\$ 1.46$ & $\$ 1.00$ & $\$ 1.39$ & $\$ 1.68$ & $\$ 2.80$ & $\$ 2.42$ \\
Family Day Care & $\$ 1.32$ & $\$ 1.74$ & $\$ 1.42$ & $\$ 1.66$ & $\$ 2.01$ & $\$ 2.39$ \\
Center/Pre-School & $\$ 1.18$ & $\$ 1.17$ & $\$ 1.70$ & $\$ 2.20$ & $\$ 2.50$ & $\$ 2.75$ \\
Head Start & $\$ 0.00$ & $\$ 0.09$ & $\$ 0.06$ & $\$ 0.33$ & -- & -- \\
\hline & \multicolumn{5}{c}{ Percentage of Hours of Free Child Care } \\
All Non-Immediate Family & $51.9 \%$ & $47.8 \%$ & $40.8 \%$ & $40.0 \%$ & $30.5 \%$ & $20.1 \%$ \\
Relative/Grandparent & $81.5 \%$ & $66.6 \%$ & $74.7 \%$ & $80.8 \%$ & $82.1 \%$ & $80.0 \%$ \\
Non-Relative & $29.0 \%$ & $24.9 \%$ & $19.5 \%$ & $20.1 \%$ & $11.6 \%$ & $6.7 \%$ \\
Family Day Care & $11.6 \%$ & $11.1 \%$ & $13.9 \%$ & $12.1 \%$ & $3.3 \%$ & $7.4 \%$ \\
Center/Pre-School & $18.6 \%$ & $24.3 \%$ & $14.0 \%$ & $10.3 \%$ & $7.2 \%$ & $6.5 \%$ \\
Head Start & $100.0 \%$ & $41.9 \%$ & $95.3 \%$ & $82.9 \%$ & -- & -- \\
\hline & Percentage of Hours Costing More Than $\$ \mathbf{1}$ Per Hour \\
All Non-Immediate Family & $30.5 \%$ & $27.7 \%$ & $44.4 \%$ & $51.5 \%$ & $61.9 \%$ & $75.5 \%$ \\
Relative/Grandparent & $8.6 \%$ & $10.6 \%$ & $11.6 \%$ & $11.8 \%$ & $10.6 \%$ & $18.5 \%$ \\
Non-Relative & $67.0 \%$ & $32.5 \%$ & $68.8 \%$ & $70.0 \%$ & $80.9 \%$ & $91.5 \%$ \\
Family Day Care & $78.4 \%$ & $80.1 \%$ & $63.6 \%$ & $77.3 \%$ & $86.1 \%$ & $90.6 \%$ \\
Center/Pre-School & $43.8 \%$ & $53.3 \%$ & $70.9 \%$ & $81.1 \%$ & $86.6 \%$ & $85.6 \%$ \\
Head Start & $0.0 \%$ & $0.0 \%$ & $4.7 \%$ & $14.4 \%$ & -- & -- \\
\hline
\end{tabular}

Source: Data are from wave 10 of the 1996 panel of the SIPP.

Standard errors: For costs per hour, standard errors range between $\$ 0.04-\$ 0.10$ for all non-immediate family, \$0.04-\$0.13 for relative/grandparent, \$0.12-\$0.24 for non-relative, \$0.10-\$0.23 for family day care, $\$ 0.10$ - $\$ 0.15$ for center/pre-school, and $\$ 0.00$ - $\$ 0.18$ for Head Start. For percentage of hours variables (second and third panels), standard errors range between 1.7-2.9\% for all non-immediate family, $1.6-3.9 \%$ for relative/grandparent, $3.1 \%-8.6 \%$ for non-relative, $2.1 \%-8.4 \%$ for family day care, $1.8 \%-5.8 \%$ for center/pre-school, and $0.0 \%-22.1 \%$ for Head Start.

Note: See Table 7 for details. 
Table 10:

Decomposing Monthly Family Income by Predicted Income Percentile

\begin{tabular}{lcccccc}
\hline & & \multicolumn{5}{c}{ Predicted Family Income Percentile } \\
Income Category & $\mathbf{0 - 1 0}$ & $\mathbf{1 0 - 2 5}$ & $\mathbf{2 5 - 5 0}$ & $\mathbf{5 0 - 7 5}$ & $\mathbf{7 5 - 9 0}$ & $\mathbf{9 0 - 1 0 0}$ \\
\hline Net Income & $\mathbf{\$ 1 , 2 6 9}$ & $\mathbf{\$ 1 , 6 3 7}$ & $\mathbf{\$ 2 , 2 9 8}$ & $\mathbf{\$ 3 , 4 3 9}$ & $\mathbf{\$ 4 , 6 6 5}$ & $\mathbf{\$ 5 , 5 7 0}$ \\
Total Earnings & $\mathbf{\$ 1 , 0 5 4}$ & $\mathbf{\$ 1 , 5 6 2}$ & $\mathbf{\$ 2 , 4 5 3}$ & $\mathbf{\$ 4 , 0 6 0}$ & $\mathbf{\$ 5 , 9 8 8}$ & $\mathbf{\$ 7 , 4 5 6}$ \\
$\quad$ Caregiver Earnings & $\$ 534$ & $\$ 641$ & $\$ 875$ & $\$ 1,216$ & $\$ 1,690$ & $\$ 2,274$ \\
Transfers & $\mathbf{\$ 2 2 3}$ & $\mathbf{\$ 1 7 1}$ & $\mathbf{\$ 1 5 1}$ & $\mathbf{\$ 1 0 2}$ & $\mathbf{\$ 5 4}$ & $\mathbf{\$ 5 0}$ \\
$\quad$ Welfare & $\$ 133$ & $\$ 107$ & $\$ 76$ & $\$ 30$ & $\$ 11$ & $\$ 5$ \\
$\quad$ Non-Welfare & $\$ 91$ & $\$ 64$ & $\$ 75$ & $\$ 72$ & $\$ 43$ & $\$ 45$ \\
Income and Payroll Taxes & $\mathbf{\$ 4 8}$ & $\mathbf{\$ 1 3 5}$ & $\mathbf{\$ 3 7 2}$ & $\mathbf{\$ 8 4 1}$ & $\mathbf{\$ 1 , 5 4 6}$ & $\mathbf{\$ 2 , 1 8 8}$ \\
$\quad$ Federal Income Taxes & $\mathbf{\$ 4 9}$ & $\mathbf{- \$ 4}$ & $\$ 138$ & $\$ 450$ & $\$ 961$ & $\$ 1,412$ \\
$\quad$ Earned Income Tax Credit & $\$ 97$ & $\$ 86$ & $\$ 72$ & $\$ 39$ & $\$ 19$ & $\$ 6$ \\
$\quad$ Child Tax Credit & $\$ 10$ & $\$ 16$ & $\$ 23$ & $\$ 37$ & $\$ 40$ & $\$ 34$ \\
$\quad$ Child Care Credit & $\$ 7$ & $\$ 6$ & $\$ 11$ & $\$ 12$ & $\$ 13$ & $\$ 19$ \\
$\quad$ State Income Taxes & $\$ 12$ & $\$ 17$ & $\$ 49$ & $\$ 106$ & $\$ 191$ & $\$ 305$ \\
$\quad$ Payroll Taxes & $\$ 86$ & $\$ 122$ & $\$ 184$ & $\$ 285$ & $\$ 393$ & $\$ 472$ \\
\hline
\end{tabular}

Source: Data are from wave 10 of the 1996 panel of the SIPP.

Standard errors: Standard errors range between $\$ 42-\$ 164$ for net income, $\$ 55-\$ 279$ for total earnings, \$31-\$167 for caregiver earnings, \$10-\$22 for transfers, $\$ 2-\$ 14$ for welfare, $\$ 7-\$ 17$ for non-welfare, $\$ 14-\$ 130$ for income and payroll taxes, $\$ 9-\$ 102$ for federal income taxes, $\$ 2-\$ 5$ for earned income tax credit, $\$ 1-\$ 2$ for child tax credit, $\$ 1-\$ 1$ for child care credit, $\$ 2-\$ 21$ for state income taxes, and $\$ 4-\$ 11$ for payroll taxes.

Note: See Table 7 for details on how predicted family income was calculated. Dollar amounts are monthly and are for the entire family, except for caregiver earnings. Net income is total earnings plus transfers plus income/payroll taxes plus other non-tax/non-transfer income. Welfare income includes Temporary Assistance to Needy Families (TANF), General Assistance (GA), and Food Stamps. Nonwelfare transfer income includes Social Security, Unemployment Compensation, Workers' Compensation, Supplemental Security Income (SSI), Veteran's Benefits, and other small government programs. Payroll taxes include the employee half of Social Security and Medicare payroll taxes. See Table 1 and the text for additional details. 
Table 11:

Decomposing the Child Care Cost Burden

\begin{tabular}{|c|c|c|c|c|c|c|}
\hline \multirow[b]{2}{*}{ Child Care Cost Burden Measure } & \multicolumn{6}{|c|}{ Predicted Family Income Percentile } \\
\hline & 0-10 & 10-25 & 25-50 & $50-75$ & 75-90 & 90-100 \\
\hline Actual Cost Burden & $5.6 \%$ & $4.7 \%$ & $5.6 \%$ & $4.1 \%$ & $4.2 \%$ & $5.5 \%$ \\
\hline Burden Without Transfer Income & $6.1 \%$ & $4.9 \%$ & $5.8 \%$ & $4.3 \%$ & $4.2 \%$ & $5.5 \%$ \\
\hline $\begin{array}{l}\text { Burden Without Transfer Income or } \\
\text { Taxes }\end{array}$ & $6.0 \%$ & $4.8 \%$ & $5.5 \%$ & $3.7 \%$ & $3.4 \%$ & $4.3 \%$ \\
\hline $\begin{array}{l}\text { Burden Without Subsidized Formal } \\
\text { Care }\end{array}$ & $8.9 \%$ & $6.6 \%$ & $7.2 \%$ & $5.2 \%$ & $4.6 \%$ & $6.0 \%$ \\
\hline $\begin{array}{l}\text { Burden With Equal Hourly Costs by } \\
\text { Mode }\end{array}$ & $9.6 \%$ & $6.9 \%$ & $7.3 \%$ & $4.5 \%$ & $3.7 \%$ & $4.2 \%$ \\
\hline $\begin{array}{l}\text { Burden With Equal Hourly Child Care } \\
\text { Costs }\end{array}$ & $12.6 \%$ & $9.8 \%$ & $8.2 \%$ & $4.7 \%$ & $3.5 \%$ & $3.3 \%$ \\
\hline $\begin{array}{l}\text { Burden Without Taxes/Transfers and } \\
\text { With Equal Hourly Child Care Costs }\end{array}$ & $14.2 \%$ & $11.3 \%$ & $8.8 \%$ & $4.8 \%$ & $2.9 \%$ & $2.6 \%$ \\
\hline Minimum Standard Error & $0.6 \%$ & $0.4 \%$ & $0.3 \%$ & $0.2 \%$ & $0.2 \%$ & $0.2 \%$ \\
\hline Maximum Standard Error & $0.9 \%$ & $0.6 \%$ & $0.4 \%$ & $0.3 \%$ & $0.3 \%$ & $0.4 \%$ \\
\hline
\end{tabular}

Source: Data are from wave 10 of the 1996 panel of the SIPP.

Note: Minimum and maximum standard errors for all of the burden measures for the given percentile group are given the bottom panel. See Table 7 for details on how predicted family income was calculated. Transfer income includes TANF, GA, Food Stamps, Social Security, Unemployment Compensation, Workers' Compensation, SSI, Veteran's Benefits, and other small government programs. Taxes included federal and state income taxes and the employee half of Social Security and Medicare payroll taxes. "Burden Without Subsidized Formal Care" assumes that all free or less than a dollar per hour care in centers, preschools/nursery schools, family day care, and Head Start cost \$2.47 per hour, the mean cost for unsubsidized formal care. "Burden With Equal Hourly Costs by Mode" assumes that hourly costs by mode are the same for all families in the sample, but hours and mode choices differ across families. "Burden With Equal Hourly Child Care Costs" assumes that hourly costs are the same for all families, but hours differ across families. See Tables 1 and 2 and the text for additional details. 
Table A.1:

Sample Characteristics By Predicted Family Income

\begin{tabular}{|c|c|c|c|c|c|c|}
\hline \multirow[b]{2}{*}{ Caregiver Characteristic } & \multicolumn{6}{|c|}{ Predicted Family Income Percentile } \\
\hline & 0-10 & $10-25$ & 25-50 & $50-75$ & 75-90 & 90-100 \\
\hline Age (years) & 23.1 & 26.7 & 29.2 & 33.5 & 34.4 & 37.4 \\
\hline Female & $96.6 \%$ & $92.7 \%$ & $95.6 \%$ & $97.4 \%$ & $98.8 \%$ & $98.8 \%$ \\
\hline White & $51.2 \%$ & $71.6 \%$ & $76.8 \%$ & $87.1 \%$ & $89.5 \%$ & $93.6 \%$ \\
\hline Black & $44.3 \%$ & $26.5 \%$ & $19.1 \%$ & $7.0 \%$ & $5.6 \%$ & $2.1 \%$ \\
\hline Other Nonwhite & $3.9 \%$ & $1.9 \%$ & $4.1 \%$ & $5.9 \%$ & $4.9 \%$ & $4.3 \%$ \\
\hline Hispanic & $33.7 \%$ & $38.1 \%$ & $20.5 \%$ & $11.9 \%$ & $4.3 \%$ & $2.7 \%$ \\
\hline Spouse Present & $33.4 \%$ & $50.8 \%$ & $66.3 \%$ & $84.2 \%$ & $94.0 \%$ & $94.9 \%$ \\
\hline Spouse Absent & $13.4 \%$ & $15.1 \%$ & $16.1 \%$ & $10.8 \%$ & $3.7 \%$ & $3.9 \%$ \\
\hline Never Married & $53.2 \%$ & $34.1 \%$ & $17.6 \%$ & $5.1 \%$ & $2.3 \%$ & $1.2 \%$ \\
\hline High School Dropout & $68.9 \%$ & $43.7 \%$ & $13.2 \%$ & $0.2 \%$ & $0.0 \%$ & $0.0 \%$ \\
\hline High School Graduate & $28.5 \%$ & $42.2 \%$ & $46.6 \%$ & $35.3 \%$ & $1.2 \%$ & $0.0 \%$ \\
\hline Some College & $2.6 \%$ & $14.1 \%$ & $39.1 \%$ & $54.4 \%$ & $28.3 \%$ & $0.0 \%$ \\
\hline College Graduate & $0.0 \%$ & $0.0 \%$ & $1.2 \%$ & $10.1 \%$ & $70.5 \%$ & $100.0 \%$ \\
\hline \# Children Aged 0-5 & 1.5 & 1.5 & 1.5 & 1.5 & 1.5 & 1.5 \\
\hline Age Youngest Child (Years) & 1.8 & 2.2 & 2.3 & 2.4 & 2.1 & 2.4 \\
\hline \# Persons in Family & 3.3 & 3.7 & 3.9 & 4.2 & 4.2 & 4.1 \\
\hline Caregiver Work Hours/Week & 16.9 & 18.6 & 22.5 & 23.8 & 22.9 & 23.5 \\
\hline All Parents' Work Hours/Week & 28.9 & 38.9 & 49.7 & 60.6 & 66.4 & 67.6 \\
\hline Non-parent Adult in Household & $52.3 \%$ & $35.1 \%$ & $23.7 \%$ & $12.1 \%$ & $6.1 \%$ & $5.6 \%$ \\
\hline Non-parent Working Adult in $\mathrm{HH}$ & $41.0 \%$ & $28.0 \%$ & $17.6 \%$ & $7.9 \%$ & $3.5 \%$ & $3.3 \%$ \\
\hline Family Income/HH Income & $68.4 \%$ & $83.0 \%$ & $89.5 \%$ & $96.2 \%$ & $98.5 \%$ & $98.8 \%$ \\
\hline
\end{tabular}

Source: Data are from wave 10 of the 1996 panel of the SIPP.

Note: See Table 7 for details. 